\title{
DLNotes2's contribution to literary literacy: a tool for literature teaching in digital environment
}

\author{
A contribuição do DLNotes2 para o letramento literário: uma ferramenta para \\ o ensino de literatura em meio digital
}

\section{Miguel Ângelo Andriolo Mangini Silvio Somer}

Universidade Federal de Santa Catarina - UFSC - Santa Catarina - Brasil

\begin{abstract}
In this article, we firstly intend to present the features of DLNotes2 - a digital platform for annotations on literary texts - as resources to study literature in digital and educational environments. To present it, we discuss the relations between printed and digital text in order to understand what changes from one to the other, the skills required in each text format and whether the platform can, in fact, provide a valid way to study literature. We propose that this digital way of studying can amplify the culture of literary literacy, despite the institutional preference for printed culture. We elaborate this discussion with the support of some theoretical references concerning literacy and hypertext, which leads to our second purpose: comprehending DLNotes2 as an educational digital platform that allows to reflexively read and comment literary texts.
\end{abstract}

Keywords: DLNotes2. Digital literacy. Hypertext. Digital literature. Literary literacy.

Resumo: Neste artigo, nós objetivamos primeiramente apresentar os atributos do DLNotes2 - uma plataforma digital de anotações em literatura - como recursos para estudar literatura em meio digital e educacional. Para apresentá-lo, discutimos as relações entre texto impresso e digital, a fim de entender o que muda de um para outro, as habilidades requeridas em cada formato de texto e se a plataforma, de fato, pode prover uma forma válida para estudar literatura. Propomos que essa forma digital de estudo pode ampliar a cultura do letramento literário, apesar da preferência institucional pela cultura impressa. Nós elaboramos essa discussão com a ajuda de alguns referenciais teóricos sobre letramento e hipertexto, o que leva ao nosso segundo objetivo: compreender o DLNotes2 como uma plataforma digital e educacional que permite ler e comentar textos literários reflexivamente.

Palavras-Chave: DLNotes2. Letramento digital. Hipertexto. Literatura digital. Letramento literário. 


\section{Introduction}

In this paper, we intend to present DLNotes2 (Digital Literature annotations) as a tool that can help to develop the literary literacy ${ }^{1}$ of readers while being used to read literary texts. DLNotes2 is a virtual platform through which the user can make digital annotations on a text. Its use requires an affinity with certain digital skills, such as the one to deal with digital hypertexts. The use of DLNotes2's digital mechanisms could assist the user improve literary literacy through a digital method of reading, writing and studying.

This article is based on concepts about literature learning and digital literacy, which we gather from some theoretical references. In section 2, the paper shows what is DLNotes2 and some implications of using it in the classroom. The third section exposes what "literacy" means and the differences and similarities between "printed" and "digital" literacies, mainly according to Carla Coscarelli (2006). In section four, the work proposes that DLNotes2 assists in the literary literacy.

\section{DLNotes2}

DLNotes2 is developed by NuPILL (Núcleo de Pesquisas em Informática, Literatura e Linguística), at Universidade Federal de Santa Catarina, in association with other professors and research nuclei from different institutions. The basic definition of DLNotes2 is: it consists of a strategic tool for teaching literature in digital environment. It is a virtual platform in which literary works are read, where the user can select a segment of the text and make annotations

\footnotetext{
1 According to Soares (2002), literacy is the reader or writer's social state of reading or writing practices, that is, the condition of one when reading or writing. It could be qualitatively measured by the level of reflexiveness, coherence and understanding performed in those practices, for example. This paper uses the expression "literary literacy" to designate a specification of Soares' definition: the state of one who is reading or writing literary texts. The skills that are put to work in this specific state are, for example, the involvement with metaphors, with poem form appreciation, observing what may be "in between the lines," etc. To develop literary literacy is to improve the performance before a literary text, so much for meditating on it as for writing it or about it. There could be a "mathematical literacy" or a "philosophical literacy," as long as they involve written culture.
}

about it, and the professor can evaluate them, as can be seen in Figure 1.

\section{$\leftarrow \Rightarrow$ C $*$ Seguro $\mid$ https $/ /$ mww.dinotes2.ufscbr/document/read/8283 \\ A Carteira \\ Texto-fonte: \\ Obra Completa, de Machado de Assis, vol. II. Nova Aguilar, Rio de Janeiro, 1994 \\ Publicado originalmente em $A$ Estação, de 15/3/1884. \\ De repente. Honório olhou para o chão e viu uma carteira. Abaixar-se, apanhá-la e guardá-la foi obra de alguns instantes. Ninguém o viu, salvo um homem que estava à porta de uma loja. e que, sem o conhecer, the disse rindo: \\ — Olhe, se não dá por ela; perdia-a de uma vez. \\ - É verdade, concordou Honório envergonhado.

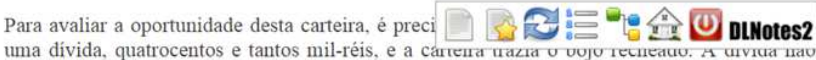 parece grande para um homem da posição de Honório, que advoga: mas todas as quantias são grandes ou peauenas. segundo as circunstâncias. e as dele não podiam ser viores. Gastos de}

Figure 1: DLNotes2's text interface (Machado de Assis's A

Carteira). Source: Source:

<http://www.dlnotes2.ufsc.br/document/read/8283>.

$(A n$

account must be created to access the text.)

At first sight, it is possible to notice the type of media or format in which the text is being supported. For centuries, the most common and traditional design of text format was the ink printed book. However, today's digital environment takes a great place in text popularization - that being DLNotes2's case. Digitized texts ${ }^{2}$ can be accessed with DLNotes2, placing the user's reading in digital environment. The tool's features for making annotations are available to the user while they are navigating through the text.

The user can make two kinds of annotation when they select a segment from the text. The first and most simple one is "free annotation": the user can choose the type of free annotation they are making for example, commentary, explanation, question, etc. -; then they are able to give a title to their annotation and write their own thoughts about the selected segment. When the annotation is finished, it becomes signalized right after the selected segment with an icon that varies according to the free annotation type chosen, popping up when clicked, as seen in Figure 2.

\footnotetext{
2 Currently, DLNotes2 can use files in XML format, which are available on NuPILL's database site for Brazilian and Portuguese literature: <http://www.literaturabrasileira.ufsc.br>.
} 


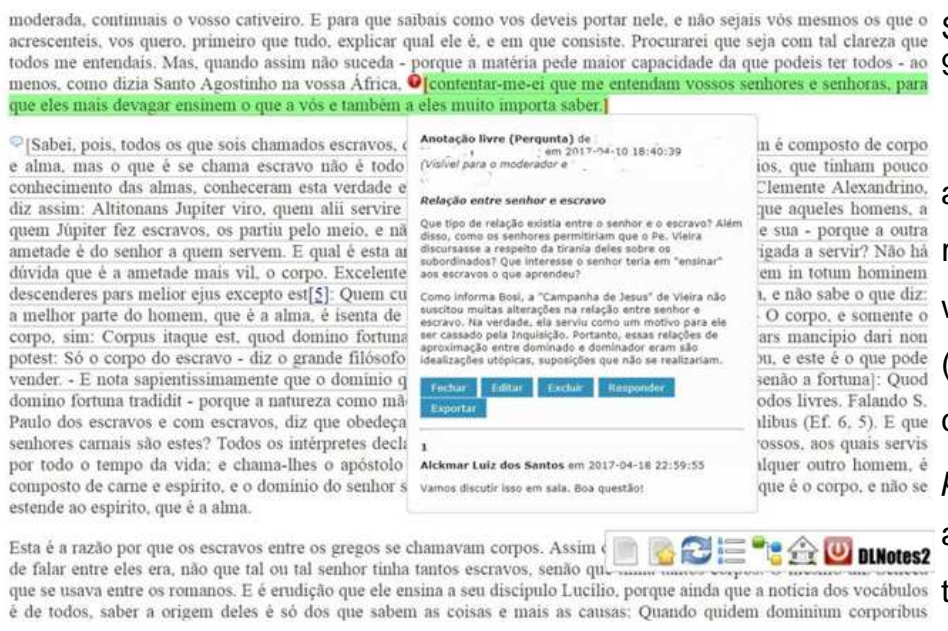

Figure 2: free annotation. The user selected the text marked in green (Padre Antônio Vieira's Sermon XXVII) and wrote a free annotation question that is indicated by a clickable question mark icon. The professor responded below. The bar on the lower-right corner arranges some DLNotes2's functions; the first, for example, is used to "hide annotations." Source: <http://www.dlnotes2.ufsc.br/document/read/5476> (An account must be created to access the text.)

The other kind is the "semantic annotation." After selecting a segment, the user can choose to make a semantic annotation, and then a window with literary theory concepts is shown. In this moment, a concept can be chosen and related to the selected text. Each concept has specific writing boxes with the purpose of adding information to the relation being established. "Character," for instance, has "name," "description," "psychological attributes," etc. In this case, the text is related, in detail, to a concept, as shown in Figure 3.

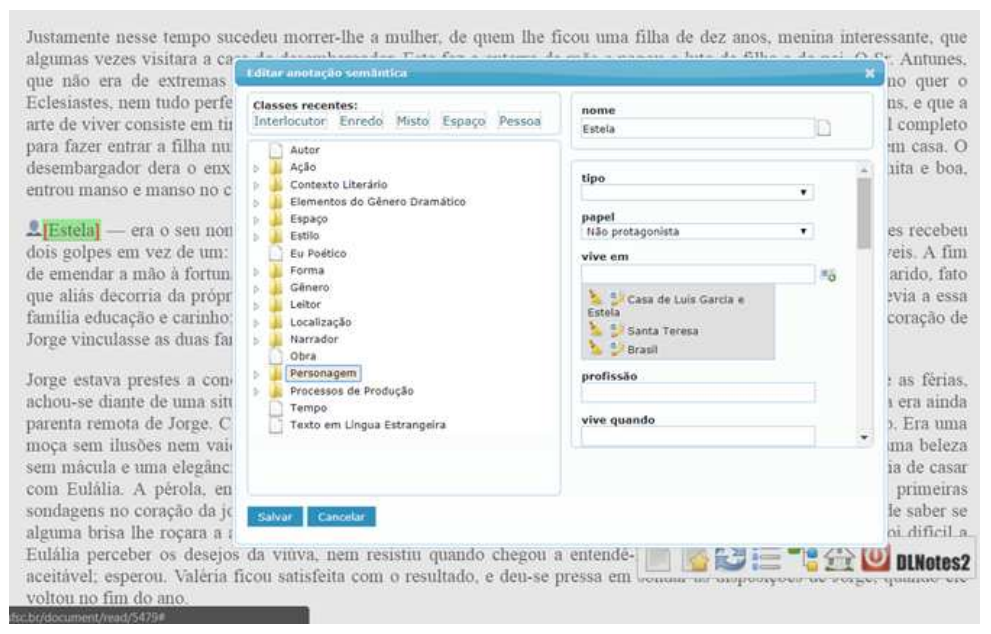

Figure 3: semantic annotation. The user selected the text marked in green (Machado de Assis's laiá Garcia) and associated the text to "character," then filled some information in the text boxes. This annotation was edited several times during the reading, because the user updates their information as they read more.
Source:<http://www.dlnotes2.ufsc.br/document/read/547 $9>$. (An account must be created to access the text.)

Some concepts available in semantic annotations can be related to others. In this case, the relation between concept and text gets detailed even with another concept. For example, "Character" (personagem, in Portuguese) has a writing space called "has personal relations with," (tem relações pessoais com, in Portuguese) in which a semantic annotation already made for "Character" is supposed to be included, for example. In this way, semantic annotations can be related to each other, creating a net, which is graphically shown, in Figure 4.

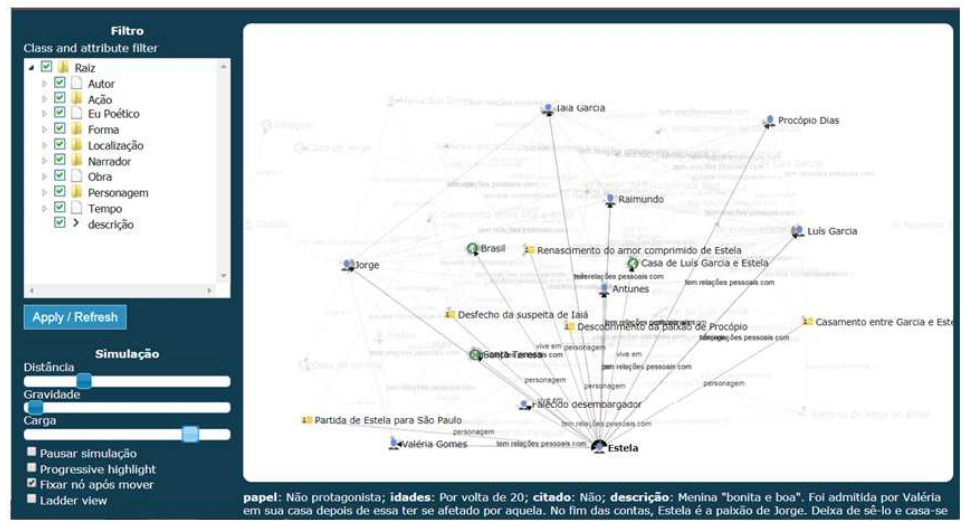

Figure 4: semantic annotation's graphical display. All the semantic annotations created throughout the reading and the relations the user established between them are shown in this display, where each icon represents a concept that the student used. Every icon can be clicked, and its information can be checked. In the left, a system of filtering is available, so that only what the user is looking for appears. Below that, there are some features to optimize viewing; "distance," for example, regulates the distance between icons. Only "Estela" and its related annotations are highlighted, since the cursor is positioned on it. Source: <http://www.dlnotes2.ufsc.br/document/read/5479>. (An account must be created to access the text.)

The purpose of these annotations would be the same as making annotations on paper, but the advantages are that they probably will never get lost and the annotation operations and functions on DLNotes2 allow the reader to make specific and conceptually rich annotations about what is being read. But the quality of the annotations depends on the reading and writing skills of who is annotating. Therefore, a professor could evaluate a student reader's annotations based on how well the content written and the concept utilization are. 
To talk about DLNotes2's educative role is now important, as it was actually designed for educational purposes. The fact that the platform, in which students write about the text being read in class, is virtual and online makes it possible for the professor to visualize the comments made by the students. Given the common demands of a literature course, the annotations evaluation process generally takes into consideration how well the student is understanding or interpreting the text and how the individual researches are going. Visualizing those annotations can be helpful for an evaluation.

Interpretation and researching are activities that DLNotes2's features help students to develop. The tool ends up helping with other skills that involve reading and writing a digital hypertext, although it is not DLNotes2's main purpose. Since the tool is a digital platform for annotations, both the linguistic and researching basic skills and the literary literacy are put to work when reading or writing. However, it is also a platform that demands the skills for dealing with a text in digital environment. Some relations between textualization and digital skills can be discussed in terms of literacy.

\section{Literacies}

Understanding the phenomenon called "literacy" is important. Magda Soares (2010) considers that the term "literacy" acquired different meanings in some countries. But the wide research made on this topic has at least one consensus: the phenomenon is related to the acts of writing and reading and its definition is often related to the act of dealing with written culture. Despite this general consent, literacy was being looked at through specific perspectives in English speaking countries, as Soares (2010) points out.

One of the perspectives is the anthropological one. It observes the social impacts of writing and reading, which varies depending on a certain cultural configuration (SOARES, 2010). The professor adds that the linguistic perspective takes literacy as the essential written text characteristics, such as letters, textual organization, etc., and the relation between them and the writer or reader (SOARES, 2010). Another perspective presented by Soares (2010) is the psychological: literacy means the cognitive competences to read or write a text.

According to the researcher (2010), literacy was understood differently in Brazil. In this country, the term was frequently associated with the reading and writing learning process. In this case, literacy is confused with alphabetization, she points out. These two processes may occur simultaneously, but literacy has to do with practicing skills of writing and reading and not with the learning stage specifically (SOARES, 2010).

Soares (2010) acknowledges the variations among perspectives for literacy, but denies it is the same as alphabetization. In another text, Soares (2002) focuses on her definition of the term. The professor defines literacy as one's condition or state when exercising reading and writing social practices, therefore performing every skill involved in those processes: basic linguistic skills for dealing with written culture and competences concerning the text's support or format.

The cognitive and linguistic set of skills seems to be necessary for dealing with any written text, meaning that a state of read or write action requires that those skills are put to use. However, Soares (2002) adds, specific text supports or formats require different skills, mainly for text navigation purposes. The author distinguishes some text formats: manuscript, codex based printed culture and cyberculture's hypertext, saying there are multiple literacies, given the many supports and their skills.

Today two text supports are the most common: printed and digital. According to Soares (2002), printed texts do not allow much variation in reading, meaning that the writer previously arranges the order in which their text will be read. The reader does not have many choices, since they are constrained to follow a pre-established linear idea organization, reading sentence after sentence, page after page, says Soares (2002). The printed text culture 
establishes a clear distance between who absorbs and who dictates the content.

Contrasting with printed text support, digital culture features the hypertext, which is non-linear and allows the reader to have a presence in the text, according to Soares (2002). Hypertext is multifaceted, composed of several links, which implicates that the text content varies depending on the continuity that the reader gives to the reading process, clicking on one link or another (SOARES, 2002). Of course, the writer has to worry about the paths that can be taken by their readers. Hypertext, then, demands a preoccupation with non-linearity.

\subsection{Hypertexts}

Soares (2002) takes printed text as something different than digital hypertext, the first having presence in printed culture and the second in digital environment. Therefore, Soares (2002) considers that one of hypertext's essential characteristics is to be in digital environment, while linear texts are defined by being in printed support, among other aspects. In this case, literacy would be determined by whether it is a hypertext or not, because that fact is directly linked to text environment and text navigation skills.

However, we consider more suitable to view hypertext from Genette's (2010) perspective. When the author deals with transtextuality types, he defines hypertextuality. According to him, the hypertext, characterized from a structural perspective, is that which establishes a relation with another text. Hypertext exists in relation to a previous text, the hipotext. He explains this relation with the example of the relation between the Aeneid (hypertext) and the Odyssey (hipotext). We propose, after what Genette (2010) said, that digital environment does not necessarily create hypertextual relations in a structural way, but at least puts in evidence the relation between two texts or more, when directing the reader from one text to another through a link. The relation could exist on paper, and the link does not create it, but rather indicates it. As noticed, the digital environment does not determine whether a text is hypertextual or not. It does not have to do with text support. Hypertextuality is intrinsic to the text, and the text environment may evidence hypertextuality to ease reading, which may be Wikipedia's function, for example.

In this paper, we agree with Coscarelli's (2006) position that hypertext is not restricted to one environment or the other. In her opinion, every text is a hypertext. It is the environment that dictates literacy, and hypertext can be in any environment: printed, digital or some other. Then, every text would demand the same basic linguistic skills; what will change are the skills to read that text in a specific environment. Thus, the text environment determines the skills required to deal with the text, and therefore the reader's or writer's literacy, not whether the text is a hypertext or not.

"To leave paper and go to a digital page will modify the navigation form in that text, but that change is not always so radical, for at least two reasons: one of them is that no text is linear and the second is that no reading is linear" (2006, p. 1, our translation). In order to show it, Coscarelli (2006) points out a series of aspects and skills required to read that turn every text into hypertext and consequently its reading too. Little changes from reading a printed text to reading in digital environment.

The fact that digital texts have links that lead to different blocks of information is commonly associated with the power of hypertext's non-linearity. However, the professor shows that the same logic behind the links can be found in traditional books, where information also can be divided into blocks - chapters, sections, paragraphs, etc. -, and the reader can guide themselves or be guided by the writer through these pieces of information. Reading is a browsing process that happens according to specific objectives.

Printed text does not impose that many limits to our reading. There are no forbidden paths in printed text from which we should free ourselves and there is no absolute freedom in [digital] hypertexts. Traditional book reading form (theoretically top bottom, right to left, following page numbering) has already been infringed by modern literature (COSCARELLI, 2006 , p. 6 , our translation). 
That was to say digital and printed texts have one common aspect: non-linearity. In this case, there is some freedom in reading, but Coscarelli (2006) adverts that reading is not absolutely free, as there are navigation limits to any text. Printed texts are as "ergonomic" and "versatile" as digital ones. So, navigation skill is not a factor that makes one of them more attractive, easier or preferable. As already discussed, neither is textualization or the text itself "better" in any of the formats.

Therefore, as the researcher puts, there are not so distinct features in digital and printed hypertexts that could make the reader or writer be more attracted to any of them. In other words, it is not the format that keeps the reader or writer attached to the text, but their objectives and desire to get information. Digital or printed do not make texts easy or hard. All depends on the person dealing with the text: the writing will have quality if the writer can achieve that; the reading, if the person has quality reading skills.

However, this equality between printed and digital text and the relation the reader or writer has with them leaves the question: "Why would any of them be chosen?"; in sum, what features does one have that the other does not? As said before, the difference is not actually between the textualizations, but between their environments. "It is possible that readings and writings [in digital era] are different, not because the texts are different, but because the production situations are distinct." (COSCARELLI, 2009, p. 560, our translation).

The main difference is that, digitally, it is necessary to deal with multimodality (COSCARELLI, 2009). Computer, screen and internet are tools that allow the presence of a hypertext with non-verbal languages, which are mostly used in digital environment. Images can be easily attached to any text, or links can direct to images; sound files can be attached to text; videos and animations often characterize digital text, etc.; and so the reader or writer must navigate through a multimodal environment, says Coscarelli (2009).

There is a specific set of navigation skills that the digital hypertext demands. To know how the computer and the web work, to be familiarized with links and acknowledge the significance of multimodal languages are necessary skills to search and produce information in digital environment. As can be noticed, these skills make what is called digital literacy. Specifying Soares's (2002) definition of literacy, a reader or writer has digital literacy when they put verbal and non-verbal navigation competences to practice in a multimodal environment.

Someone who navigates through digital hypertexts is in digital literacy state. Some people know web interfaces and then navigate it more easily than others, and some have better reflexive and critical performance when reading or writing the verbal text. However, Coscarelli (2009) argues that there should be a balance between printed and digital culture: each one has a number of its own features. But she adverts there was cultural resistance against digital written culture, which may still be a problem.

\subsection{Preparation for digital literacy}

Coscarelli (2006) points out similarities between printed and digital texts to question the printed culture preference that was resisting against the new digital reality, such as in schools and in general reader and writer public. According to her (2010), schools in Brazil were not quite preparing students to deal with computers and, therefore, with the digital universe of texts. The researcher says that schools, in every education level, remained with the preference for a printed culture literacy.

It is more likely that a child has contact with digital technological devices since birth than with printed books - now even more than when she wrote the essay. This means that texts are going to be presented to that child digitally. Despite this, for Coscarelli (2010), the Brazilian educational system did not acknowledge the condition of children that live in a digital world, because education generally does not coach or guide its students through digital environment in alphabetization phase, but rather insists mainly on printed culture. 
Children will be involved with the digital environment with or without school's preparation, so the choice to ignore digital alphabetization and literacy is counterproductive: "Today, children can make films in their cellphones, can make animations with programs in the computer, can put sounds, many colors, different fonts and animations in their texts. And who will teach them all of that?" (COSCARELLI, 2010, p. 515, our translation). Coscarelli (2010) asks whether that is the parents' or the school's role.

It is likely that both should have a contribution in digital alphabetization and literacy, but school and home are different environments for different events and objectives. Coscarelli shows that children are aware that school is not a "playing" place, they know they are there to learn something important, whereas at home kids feel freer to play. She affirms that applies to computer use: children can play games at home, but in school they should be learning how to write and read digital hypertexts.

Actually, dealing with digital texts requires some technical skills, such as moving the mouse, searching for information on the web, knowing text producing programs, etc. (COSCARELLI, 2010). School was not being so supportive of digital literacy and alphabetization. Ana Ribeiro and Coscarelli (2010) analyze this situation, verifying that one of the main evaluation tests for basic education in Brazil, SAEB (Sistema de Avaliação de Educação Básica), did not consider skills for digital culture.

Less than that, SAEB did not take into account technical skills for computer and other digital technical devices. A national evaluation test has a set of skills by which it can judge the education system quality and achievements. That set is called a matrix. SAEB's matrix consists of basic linguistic skills for reading a text, without considering the support in which the text may be. The researchers say the test judges education without acknowledging that the format is an important part of the text.

SAEB's matrix main evaluation focus are the skills to reflexively and critically read and interpret texts - mostly written, but non-verbal in some cases -, identifying sense effects, speech figures, etc.
However, it does not consider "typical digital environment elements, such as digital hypertextuality, interface elements" (RIBEIRO, COSCARELLI, 2010, p. 324, our translation). Attention to skills to navigate through digital multimodality is missing; to navigate is part of reading, so it should be considered.

Considering the lack of attention to the growing involvement that people have with digital written culture, Marcelo Dias and Ana Novais (2009) propose a matrix of new skills that schools and educational institutions should consider in order to improve digital literacy and alphabetization processes in the digital era. The researchers' motivation is that "The computer, when compared to the book or annotation, shows a much bigger variety of tasks to be realized" (2009, p. 5, our translation). Those new tasks are related to multimodality.

More multimodal languages available means more options and different technical skills that the reader or writer must have to use efficiently. The matrix proposed by Dias and Novais (2009) intends to contemplate those skills and was divided into four general topics: to know and use different program and site interfaces; manage, browse and save information in the web; navigate through hypertext and links; produce written or oral hypertext with the tools that the digital environment gives: links, multimodality, etc.

It is evident then that an individual is considered to have digital literacy when they have those four general skills added to the basic linguistic and cognitive skills to read or write a hypertext. Whether educational institutions embrace or not Dias and Novais's (2009) matrix, it is not this article's focus, but rather how DLNotes2 can contribute to the student's literacy, making profit out of the digital literacy, taught or not by school, countering, then, institutional preferences for printed text that resist the demands of digital era.

\section{DLNotes2 as a tool for literary literacy development}

DLNotes2 is not appropriated for alphabetization processes. In its actual stage, it 
supports literary texts, which already assume the proficiency of basic reading and writing skills. But they do not naturally demand digital environment navigation skills. This paper's proposal, then, is that DLNotes2 can help the student improve their literary literacy, by using those navigation skills to make a profitable use of digital mechanisms to study. In this case, the digital annotations are intended to beneficiate "raw" and literary textualization competences.

At this moment, we concentrate on the annotations and how the students can make an efficient use of them. Students that are little experienced with literature may get surprised by literary strangeness. Normally, that strangeness would not be explored and the reader's conclusion about the text would be only some emotion. However, it is frequently required of the student that they write their interpretation or point of view, which is an exercise that stimulates reflection about the literary text and the identification of metaphors, formal choices and narration structures, etc.

The free annotations make the reflection writing possible. In a general way, it is important to write annotations, as it is an act of memorization and studying, which can be complemented later by reading the written annotations and then the text. In DLNotes2, annotations are available in a list above the original text that shows every commentary made by the user. When an annotation is clicked on this list, the text scrolls to where the annotation was created, and the segment associated with it gets explicit in green, as in Figure 5. This way, the annotation course can be recalled.
Comentário de 2017-05-01 12:48:38

O zelo que finge todo tirano é, também. destoante na tradiçăo da Igreja Católica, a cuja religião referiu-se. Gonzaga, algumas vezes nas "Cartas". Assim como, conforme Nietzsche (2012), os sacerdotes, os homens poderosos e os apologistas do dogma teligioso exercents sua dominaçăo através da referéncia ả autoridade divina e valoraçăo da compaixào - sentimento que, segundo o filósofo, reduz o próximo à miserabilidade - $\mathrm{o}$ tirano "Fanfarrào" emprega de forma seletiva esse zelo religioso e finge a compaixăo, a piedade, no inicio do desgoverno para tormar o poro dependente dele enegado a ele

W. Anotação semântica de Alckmar Luiz dos Santos em 2017-05-12 14:26:37 (Visivel para todos.)

The of belongs to Alckmar Luiz dos Samtos.

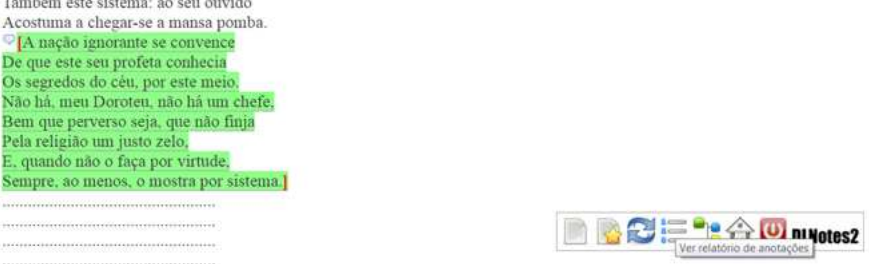

Figure 5: annotation report. The user selected the text marked in green (Tomás Antônio Gonzaga's Cartas Chilenas) and wrote a free annotation. By clicking the list icon in the lower-right corner bar, the list above the text is shown with all annotations, including the professor's, Alckmar dos Santos, in this case. The green text was shown when the balloon icon in the upper-left corner was clicked. Source: <http://www.dlnotes2.ufsc.br/document/read/5480>. (An account must be created to access the text.)

The same logic of reflection writing is behind semantic annotations. Annotating semantically offers a more theoretical approach to literary texts, because, in this case, the user registers their thoughts through literary theory concepts. Many of the concepts may be unknown to the user, such as "spherical" specification in "character," but their meanings can be inferred, if not researched for, and used anyway. Using literary concepts - like "character," "space," "style" - gives a more precise or solid condition to a consideration.

By associating a text excerpt with "literary context," "time/literary movement," and, finally, "Latin literature," the student is defending that the text they marked is related to these concepts, and by choosing some concepts instead of others, they mean they are reflecting among many options, figuring out which one has more to do with their position. Of course, that means they reflect about some concepts, getting experienced through a more formal approach of literature. The use of that would be to make precise annotations and consistent study.

Semantic annotations assist the student in considering literature through concepts, which can help to apprehend the text or make interpretations, as they can articulate their writing based on a preexisting concept - a "head start." Then, it is also possible to connect two annotations. In the end, the semantic commentaries will be interconnected, and 
each one will be evidence for a particular interpretation or will represent highlight points for a reading course. As shown in Figure 5, the semantic commentaries will be graphically displayed, so they can be dynamically studied later.

Graphic observation is a considerable way of studying - has always been and is today endorsed by the multimodal language environment. Semantic annotations should be studied graphically, since every commentary made and the relations between them, each one with its conceptual specifications, will be easily viewed. Also, they can be filtered, so that only "characters" appear on the screen, for example. The use of concepts helps to formally define events in the text and then correlate them for further studying. The student's literary literacy skills could be improved using semantic annotation.

However, it is possible that taking reflection annotations and studying them could be motivated only by the educational institution, where DLNotes2 is most efficient. The tool is mainly destined to education, so that an interaction between student and professor can be done. The online interface allows the professor's access to its students' annotations. In a classroom situation, one adequate process would be to evaluate the student's literary literacy based on the number and quality of free, semantic or both types of annotation.

Depending on the level of education, basic or higher, a professor would have specific demands for the students' annotations. In a higher education literature class, to do some bibliographical research would be required to make annotations, in a way that the student's reflections on that literary piece would be deepened; and/or the user would have to make a consistent interpretation, extracting evidences from the segment they chose to write about. In both cases, the reader is improving contact with literary language, their literary literacy.

Probably, basic education would not demand such meditated writing and reading. That means the literary literacy gets more evolved depending on the user's objectives and motivation, which, of course, are stimulated by the educational level. DLNotes2's digital interface articulates that stimulation, given the professor's demands and ability to access students' annotations. The fact that it is digital comes with the need of digital literacy: the user should get used to dealing with some basic navigation skills present in the platform.

In fact, the annotation process - with which the reflection writing comes -, gets more easily done as the user becomes more skilled with DLNotes2's interface. The interface for free annotations familiarizes the user to "jump" from a point to another in the text, when the annotations are done. The user navigates through a text that is now marked with their own writing. It can be said that the student becomes a co-author. Also, the association of the user's ideas with the text itself and the "jumping" navigation make it more evident that it is a hypertext.

On the other hand, semantic annotations interface may be a little more distinct from traditional digital interfaces. Until the annotation making is done, the process is quite similar to free annotations, but the web graphic disposition of semantic annotations is where the digital hypertext multimodality is more perceptible. Now the user's state of reading and writing is such that they manage icons that contain their interpretations and with image, while filtering some concepts and moving them around. Multimodality skills are put to work.

In that case, digital literacy was important for the student to make an advantageous use of DLNotes2's annotations, since they had to navigate through digital environment. If the user had underdeveloped digital skills, they now know how to navigate many internet pages and programs, because a part of DLNotes2's interface is essentially similar to others - it has clickable buttons, a system of scrolling and information filling windows. And the other part prepares the student for a frequent digital phenomenon: multimodal languages.

However, it is important to stress that DLNotes2's objective is the other way around: it uses the digital environment tools aiming for literary literacy improvement, and not the literature for an improvement on digital literacy. DLNotes2's 
annotations make it possible for users to navigate through a hypertext and they do it through the digital tools that the platform provides. Students might achieve a better level of literary literacy by writing their reflections, "freely" or "semantically," and revisiting these annotations, that benefit from modality and dynamicity, in contrast to the paper ones.

Finally, these were some advantages of reading and writing a hypertext in DLNotes2 that could be helpful to the educational environment, for which the platform is dedicated. Students may or may not be assisted by school nowadays concerning digital literacy, although developed digital literacy allows to access new learning technologies, even to ease the contact between professor and students. Concerning this issue, we show a digital technology that promotes education in the digital era, which contributes to the students' literary literacy by offering digital approaches to literature.

\section{Final considerations}

This paper presents DLNotes2 as a digital platform that can offer new approaches to literary literacy, as the student, in educational environment, gets stimulated to reflect about the text with the digital resources. The tool is crafted with the thought that digital mechanisms can help penetrate the eternal study object that is literature. Literature is hypertextual as always, but digital environment may show it more clearly with a non-linear approach allowing the use of multimodal languages to study, which is proposed to be DLNotes2's function. letramento. Belo Horizonte: Editora UFMG, 2010. p. 513-526.

Os dons do hipertexto. Littera, Pedro Leopoldo, v. 4, n. 4, p. 7-19, July/Dec. 2006.

Textos e hipertextos: procurando o equilíbrio. Linguagem em (Dis)curso, Palhoça, v. 9, n. 3, p. 549-564, Sept./Dec. 2009. Available in: <http://www.scielo.br/pdf/ld/v9n3/06.pdf>. Access in: 30 Jan. 2018.

DIAS. M. C.; NOVAIS, A. E. Por uma matriz de letramento digital. In: ENCONTRO NACIONAL SOBRE HIPERTEXTO, 3., 2009, Minas Gerais. Proceedings... Minas Gerais: CEFET-MG, 2009. p. 1-19. Available in: <http://nehte.com.br/hipertexto2009/anais/p-w/poruma-matriz.pdf>. Access in: 30 Jan. 2018.

GENETTE, G. Palimpsestos: a literatura de segunda mão. Belo Horizonte: Viva Voz, 2010.

RIBEIRO, A. E.; COSCARELLI, C. V. What skill matrices convey about reading in digital environments. Educação em Revista, Belo Horizonte, v. 26, n. 3, p. 317-334, Dec. 2010. Available

in: <http://www.scielo.br/scielo.php?script=sci_arttext \&pid=S010246982010000300016\&lng=en\&nrm=iso>. Access in: 30 Jan. 2018.

SOARES, M. New reading and writing practices: literacy in the cyberculture. Educ. Soc., Campinas, v. 23 , n. 81 , p. 143-160, Dec. 2002. Available in: <http://www.scielo.br/pdf/es/v23n81/13935>. Access in: 30 Jan. 2018.

Práticas de letramentos e implicações para a pesquisa e para políticas de alfabetização e letramento. In: MARINHO, M.; CARVALHO, G. T. (Org.). Cultura escrita e letramento. Belo Horizonte: Editora UFMG, 2010. p. 54-67.

\section{COMO CITAR ESSE ARTIGO}

SOMER, Silvio; MANGINI, Miguel Ângelo Andriolo. DLNOTES2'S CONTRIBUTION TO LITERARY LITERACY: A TOOL FOR LITERATURE TEACHING IN DIGITAL ENVIRONMENT. Signo, Santa Cruz do Sul, v. 43, n. 78, nov. 2018. ISSN 1982-2014. Disponível em: <https://online.unisc.br/seer/index.php/signo/article/view/12034>. Acesso em: doi: https://doi.org/10.17058/signo.v43i78.12034.

\section{Referências}

COSCARELLI, C. V. A cultura escrita na sala de aula (em tempos digitais). In: MARINHO, M.; CARVALHO, G. T. (Org.). Cultura escrita e 